\title{
Roman defence sites on the Danube River and environmental changes
}

\author{
D. Constantinescu \\ Faculty Material's Science and Engineering, \\ University Politehnica of Bucharest, Romania
}

\begin{abstract}
There are many things to learn from the past regarding ancient settlements, the ancient organization of cities, the structures of the buildings and concerning the everyday life of our ancestors. There are numerous sites along the Danube River which were once included in the economic and defensive system of the Roman Empire. Many of them are not well known today or studies are in their very early stages. Sucidava is an example of a Daco-Roman historical defence site, situated on the north bank of the Danube. The ancient heritage site covers more than two hectares; comprising the Roman-Byzantine basilica of the 4th century, the oldest place of worship north of the Danube, the building containing the hypocaust dates from the late 6th century $\mathrm{AD}$, Constantine the Great portal bridge, to span the Danube river, the gates linking the bridge and city, a Roman fountain dating from the 2nd century AD. This entire defensive and communication system stands as a testimony to the complexity of an historical conception. However, how was it possible that such sophisticated structures have been partially or totally destroyed? Certainly not only economic and military aspects might be a likely explanation. The present article considers the evolution of the sites from cultural ecology point of view, as well as taking into consideration environmental and climatic changes. Doubtless, the overall evolution of this site is not singular. This article proposes some comparisons with other representative roman cities located on the River Rhine. It is proposed to analyze the particular characteristics of this fascinating example of European heritage, and the influence of environmental factors on the degradation process. Keywords: historical site, defence, climate changes, conservation, Danube.
\end{abstract}




\section{Introduction}

When examining ancient historical sites, it is often possible to discover a large number of aspects which may change our initial assumptions and points of view. Thus, it is necessary in many cases to distinguish between legends, traditions, scientific knowledge and the reality. The present article is not an article focused to establish some historical facts; simply attempting to put forward questions from an environmental point of view regarding the evolution of such a fascinating and little known historical site. The mutual impact of the defence site and the environment in addition to human activities in such ancient settlements is certainly remarkable. One should not be surprised by certain distinct similarities between sites located at a considerable distance to each other, which will be touched on later. It is necessary to have in view some global evolutions if we wish to understand the present situation and to have an idea about how it will be the evolution of our eco-culture, our environment and probably our everyday life.

The site which is today known as "the historical site of Sucidava" is a good opportunity to attempt to answer some environmental problems and, put forward a number of new questions. The Danube River, connected historically and environmentally to the Rhine River (may be more as we have supposed till now), is a special environmental system. Just as it poses many questions and challenges even today, so many answers to its history elude us still. From a military, economic and strategic point of view, Sucidava was one of the most powerful centres in the South Dacia. Following the Daco-Roman wars (first 101-102, and second 105-106), the roman civil settlement developed and after AD 106 extended its settlement to approximately 22 hectares. The city with a population of 3000 was surrounded by trenches and defensive walls (Bâciu and Vârtejaru [1]).

\section{Location of the Sucidava defence site}

The GPS coordinates of the site are: $43^{\circ} 44^{\prime} 05^{\prime \prime} \mathrm{N} ; 24^{\circ} 30^{\prime} 05^{\prime \prime} \mathrm{E}$, locating it in the Oltenia Champs, not far from the confluence of the Olt River to the Danube as shown in figure1 (Anastasiu [2]). Figure 2 shows a detail regarding location of the Sucidava site, near the actual city Corabia.

The ancient name of the site is considered to be "Sykibid", after Procopius from Caesarea (Karagiorgu [3]), and mentioned as "Sucidava", ( Lucidava where $\Sigma$ is pronounced as English "sh") - by V. Pârvan (Pârvan [4]). The earliest mention of Sucidava by name, can be found in an inscription from the 3rd century $\mathrm{AD}$, in the Roman-Byzantine fortress. The site is considered a DacoRoman site, located on the north bank of the Danube. From historical and archeological point of view, Sucidava proves an uninterrupted activity and occupation from the period of emperor Aurelianus (270-275) to Theodosius II (408-450). It means an economical and social activity, proved by the presence of coins (figure 3). The archeological evidence shows that in AD 443 and 447 the city suffered from the attacks of Huns. However, it seems that the Castrum was restored under 


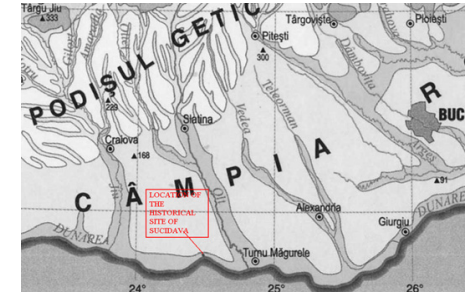

Figure 1: Location of the historical site Sucidava.

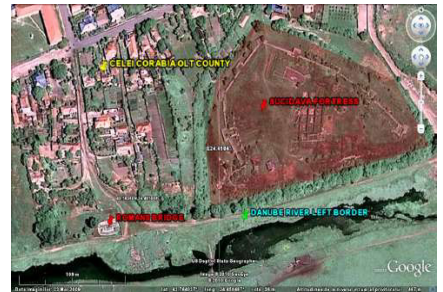

Figure 2: Details regarding the location of the site and limits of the ancient castrum (Google Map).

Emperor Justin I (518-527) or Justinian I (527-565). Around the year 580, it seems that the Roman garrison (part from the Vth Legion Makedonica) abandoned the Castrum, probably after many concentrated Slaves - Avars attacks. After the year 600 the social, cultural and economic activity ceased for many centuries.

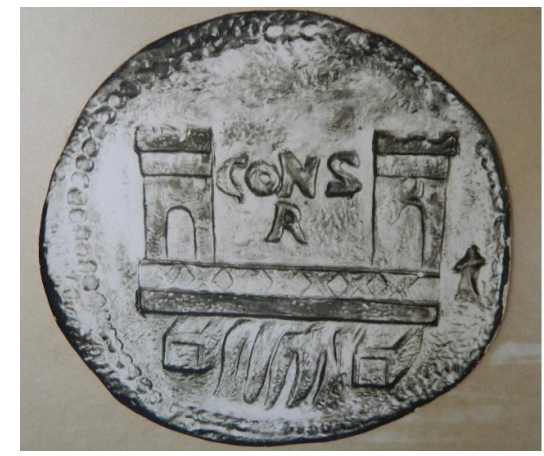

Figure 3: Roman coin conserved at museum of Sucidava (photo: L. Mitroi, Sept. 2011).

Today, the best conserved and studied area is the ancient defence fortress (castrum), delimited by the Roman and Byzantine walls. This area has had a great influence not only from a military point of view, but also as a protection of the social, economical and cultural life of the city. Figure 4 illustrates these limits, as it results from the existing documents in the Sucidava Museum.

\section{Neighbourhoods, fortresses, people and environment}

It seems that the "retreat" of the Roman Empire was well coordinated, occuring in the period AD 250...270. Then, after a short period of about 250 years of coming back, it follows the general retreat in the years 580-600. 


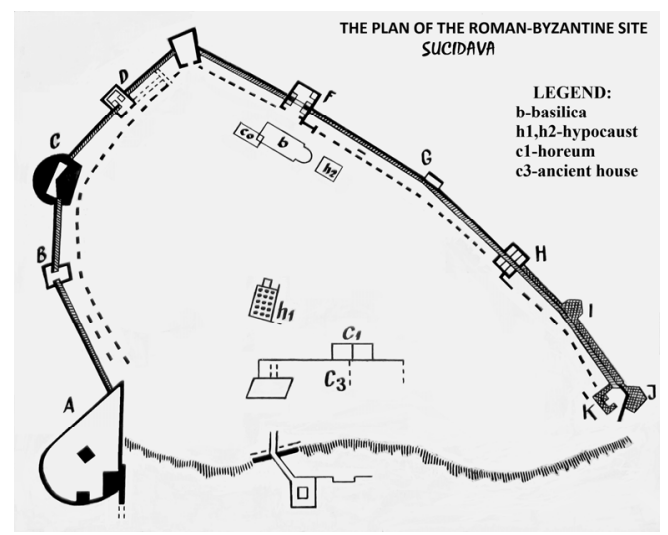

Figure 4: $\quad$ Limits of the ancient castrum, Roman and Byzantine walls.

The situation was significantly similar on the Danube (including the inferior Danube) and on the Rhine, including the north. Analyzing the documents and the maps of Abraham Ortelius and the archeological sites, some aspects can't remain unremarkable. Figure 5 presents a section of a map (DACIARUM, MOESIARUM QVE VETVS DESCRTIPTIO) (Ortelius [5]), included in the history section of the work “Theatrum Orbis Terrarum”, edited in 1570.

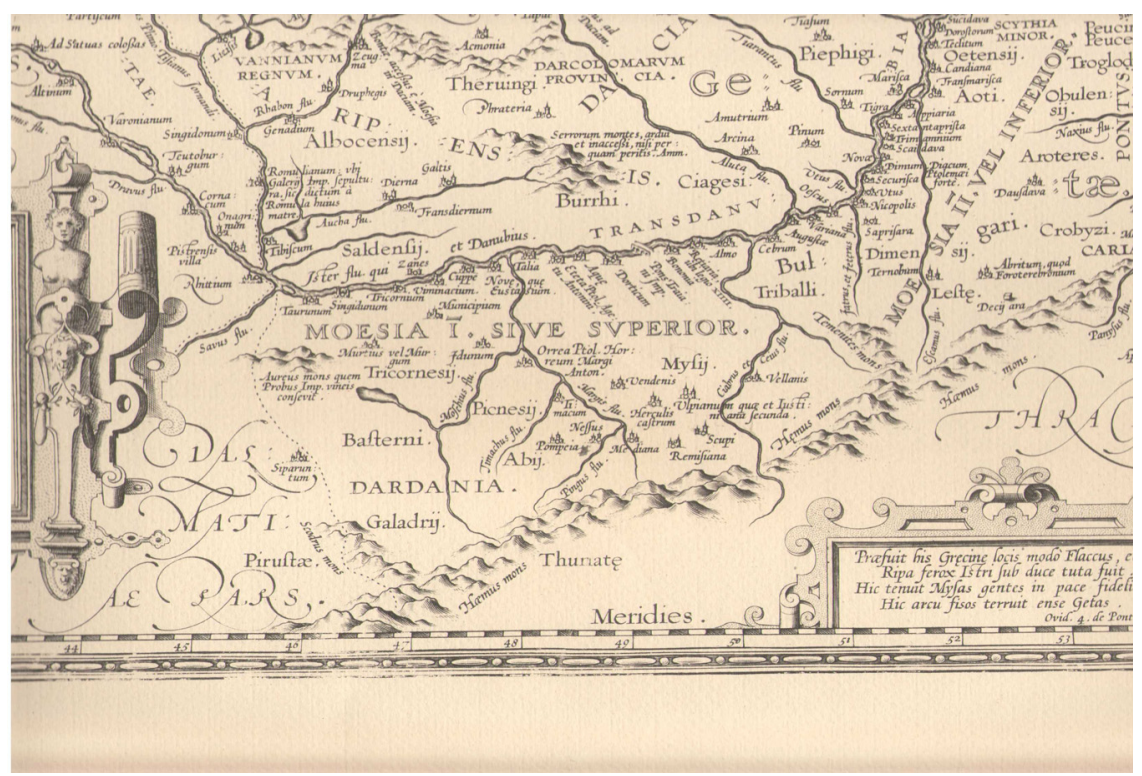

Figure 5: Danube River, Daciarum and Moesiarum, after the map of Ortelius, (edition 1595, The Netherlands). 
The chain of fortresses built along the Danube starting from the Drava River (Dravus) till the Danube Delta is remarkable; a similar aspect occurring also along the Rhine River, corresponding to the same historical period. In some geographical and historical works (Ortelius [5]) "Dacia" and "Moesia" are treated together, starting from sources that mention the existence of some "Daciae et Moesiae", both on the north and south banks of the Danube.

Regarding the name of the people from these territories, some changes can be noted, depending on the period and the authors, which may be explainable by a high dynamic in the territorial administration in the Roman Empire. Commonly, Latin authors use the name "Dacum" and the Greek authors use the name "Getae". However, Suetonius make a difference [5], explaining that "Dacum" are in the western territories and "Getae" in the eastern territories. In any case, it seems that the Roman Empire paid close attention to their relations with this people. Few bridges connected the cities and the fortresses existing on the both sides of the Danube River. It is to remark on the map in figure 5, the name "Pons Traianii Imperator", and its position on the Danube.

The bridge build at the order of Emperor Constantine the Great, included as component of a defensive and probably also an offensive system, connecting Sucidava with Ulpia Oescus, all of which is evidence of the intense activities during the period 250-450.

There are a lot of reasons to suppose that the climate and the ecosystems were different from what is observable today. The aspect of the rivers was different as we know them today, if we pay close attention to the maps of Ortelius for example. However, the sources of water were likely a problem for some cities, especially during times of war. It is interesting to mention the following remark of Ortelius [5], (after a citation of Philargyrus and Aufidius Modestus): "when they (ref. to the Dacs) go to war, they do not start before drinking some quantity of water from the Ister (Danube River), so as if they drink the holly wine, and they swear not to return home in their country before destroying the enemy. Therefore, Virgilius called this river "Istrum coniuratum".

\section{Strategic buildings and vestiges in Sucidava historical site}

The territory of the Daco-roman Sucidava was organized following a schema, typically used for many important roman cities: a polygon with four sites very well and logically divided, according to local particularities (figure 6 and 7).

The excavations and research in the area of Sucidava have brought to light many interesting aspects (Hampartumian [6]).

The enclosure walls and towers of entry (Toropu and Tatulea [7]). In these fortification buildings are included the West Gate. The West Gate that links the bridge of Constantine with the city dates also from the 4th century. The traces of roman carts that passed through the entrance to the fortress and to the city are visible to this day (figure 8). It is of interest to mention the material used for the walls: there are local rocks, with visible traces of Paleolithic shells, proving the dramatic climate and geological changes, two and a half million years ago (figure 9). 


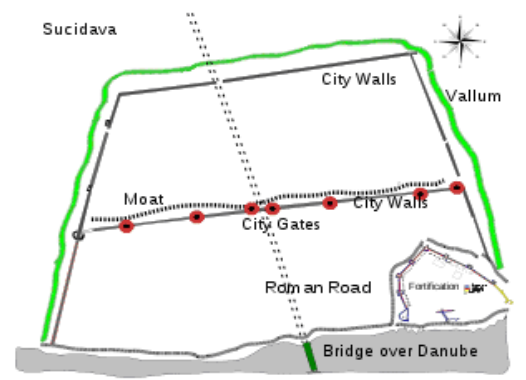

Figure 6: General organization schema of the Sucidava site.

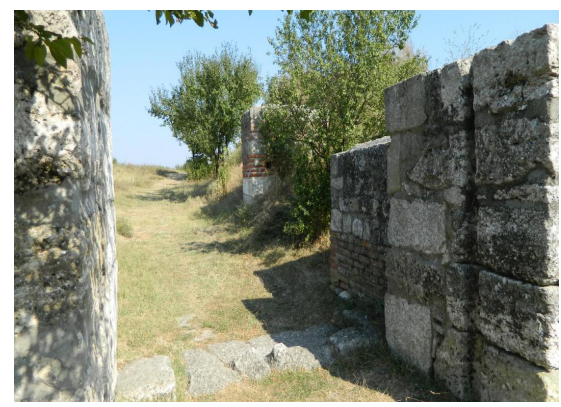

Figure 8: Walls, north gate and marks for the roman carriages (photo: D. Constantinescu, Sept. 2011).

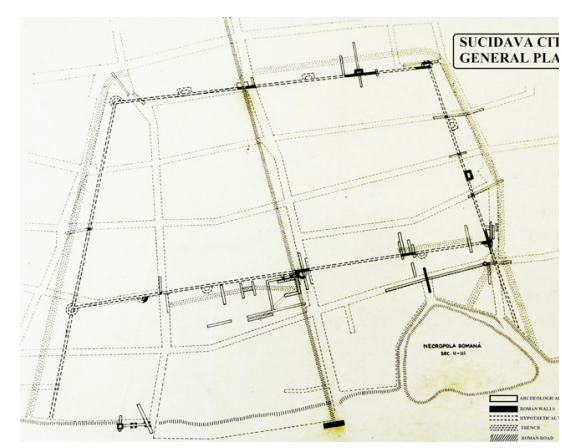

Figure 7: Map of the Sucidava site from the museum (photo: L. Mitroi, Sept. 2011).

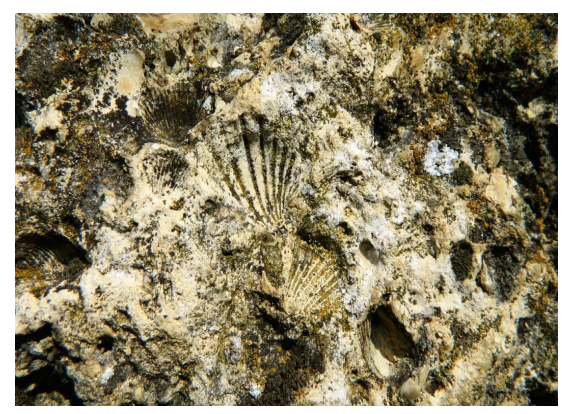

Figure 9: Details from the wall of the fortress (photo: L. Mitroi, Sept. 2011).

Roman-Byzantine Basilica - dates from 6th century; is the oldest architectural religious structure of its kind found north of the Danube. It was discovered during 1946/47 in the Northwestern corner of the city. The building has been preserved in some of the foundation walls and interior floor. The church conforms to a rectangular shape with a semicircular apse with a radius of $3.80 \mathrm{~m}$ representing the altar, facing east-southeast. The thickness of the foundation walls is $0.65 \mathrm{~m}$, the entire building being made of stone and brick walls. Under the brick floor of the basilica, were found six graves (Hampartumian [6]) lying on an east-west axis, conforming to typical Christian rituals. A tomb near the altar was kept in place, where archeologists found a $1.96 \mathrm{~m}$ skeleton, although at that time people barely reached $1.60 \mathrm{~m}$ in height (Tudor [8, 9]). 
An ingenious heating system with hypocaust ("thermae") was discovered in 1977. Heating was carried by ceramic tubes buried in the walls of the house. The building is rectangular and has dimensions of $11 \times 5 \mathrm{~m}$ by 0.45 and $0.65 \mathrm{~m}$ thick walls. Its floor (a fragment of which was preserved) that has been restored was supported by 8 rows of 22 pillars. In the space beneath the floor warm air circulated from a furnace (praefurnium) located outside the building. In this way heating reached this important building, possibly the commander headquarters (Toropu and Tatulea [7]), (Tudor [10]). But, it is more probable that the building was a typical roman bath. In figures 10 and 11 a very interesting heating system used at the Sucidava, similar to the system used in other important roman cities, can be observed (e.g. Augusta Raurica).

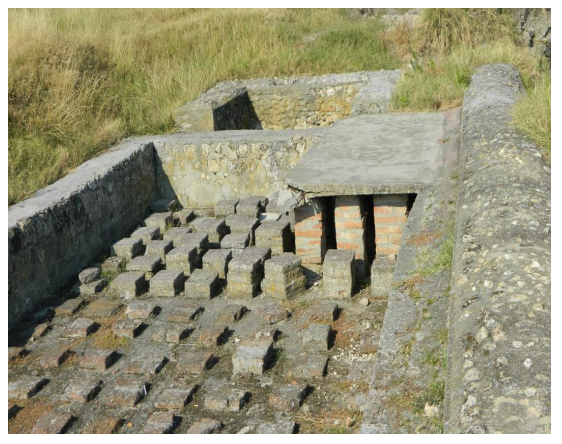

Figure 10: Hypocaust - the heating system used at Sucidava.

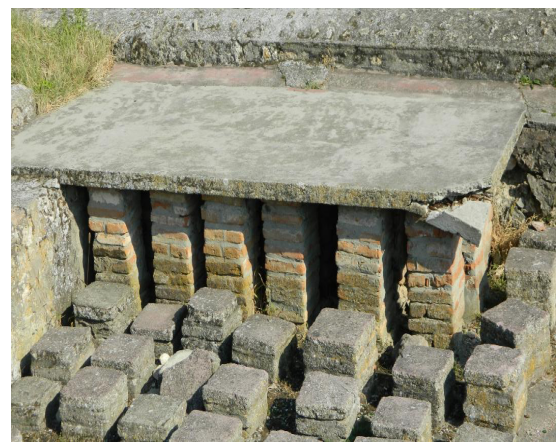

Figure 11: Detail of the hypocaust (photo: L. Mitroi, Sept. 2011).

The water source of the fortress - seems to be the most disputed and mysterious vestige of the site. Named also "Secret fountain", it is an underground construction with two components: the shaft itself, at a depth of about 18 meters from the ground level of the city, and an access corridor 26 meters long, which descends to a source inside the defence site. In the late 6th century, the Sucidava military garrison water supply was more problematic than in previous centuries due to possible changes in the climate and the environment which might have reduced the water level. Nearby, the city with its fountains no longer exists. The use of springs at the foot of the plateau was not possible in case of floods, especially during sieges, when they were controlled by the invaders. However, there are only suppositions. On the other hand, the layer structure beneath the platform of gravel and sand being alluvial of origin, did not allow digging of deep wells, which would have collapsed during drilling. Restored and open to the circuit of cultural tourism since 1968, it remains the most attractive archaeological vestige of the site. In figures 12 and 13, the access tunnel to the water level and the pyramid built above the water source can be observed.

Emperor Constantine's bridge. One of the most important defence vestiges to observe are the pylons of a bridge known as "the bridge of Constantine". In the 4th century, Emperor Constantine the Great rebuilt the city and constructed the 
bridge over the Danube between Sucidava and Ulpia Oescus on the right side of the Danube. Approximately $2437 \mathrm{~m}$ long, it was one of the longest bridges of antiquity (figure 14). The emperor issued a medal when inaugurating the bridge in 328, (Tudor [10]). All what it is possible to see now from this great bridge is only a part of one pylon. It seems that the period in which the bridge was used is not very long (from 328 until the middle of the 4th century (Gherghe et al. [11]).

However, the existence of the bridge provides evidence of an intense military, commercial and cultural activity.

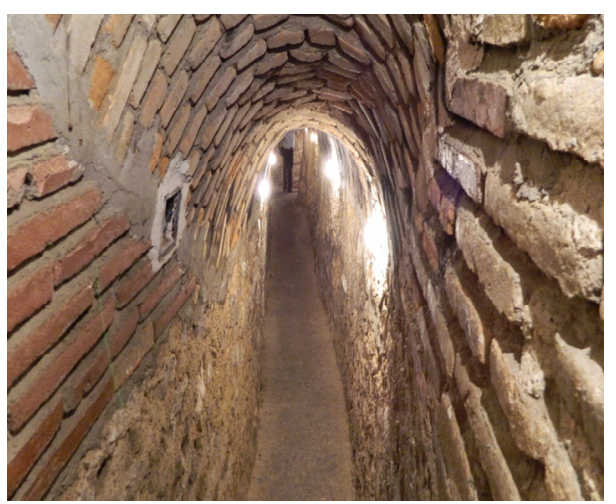

Figure 12: Access tunnel to the water source level (photo: L. Mitroi, Sept. 2011).

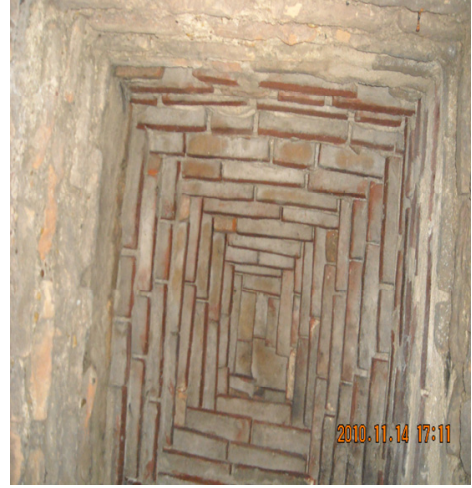

Figure 13: Pyramid built above the water source (photo: D. Constantinescu).

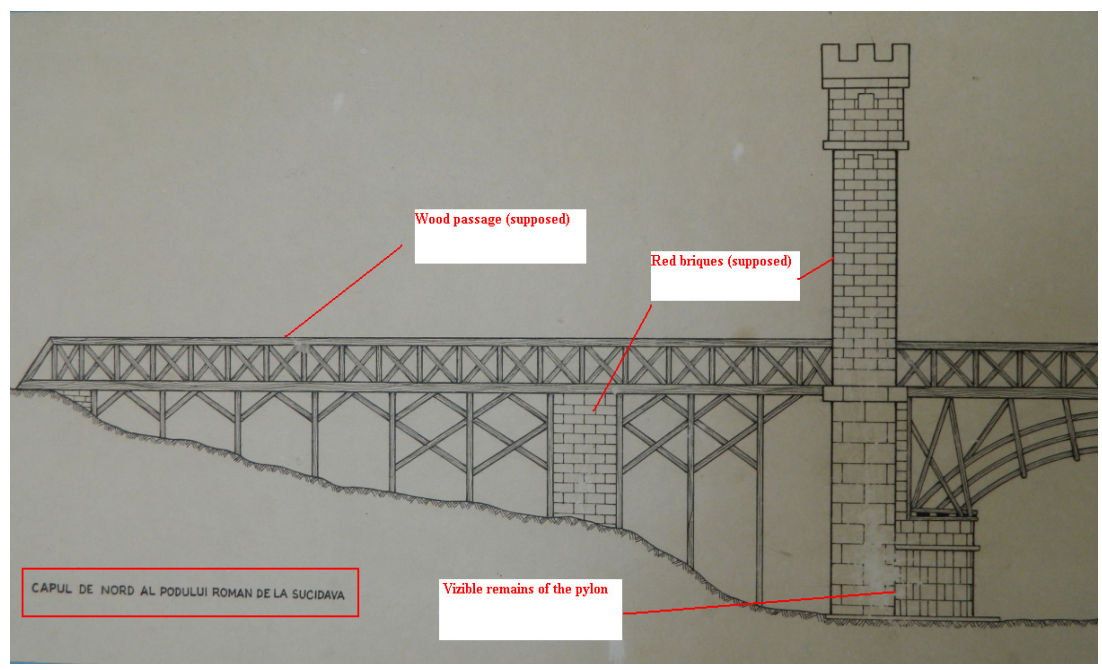

Figure 14: Supposed reconstruction of the Emperor's Constantine Bridge (Sucidava museum, 2011). 
What can be supposed? Comparing the site of Sucidava with other Roman and Roman-Byzantine sites, it would appear that something is missing from Sucidava which are the amphitheater and the temple. If there is no information about the amphitheater in the documents or as results of archeological researches, it seems that there is some information about the temple. It was a temple dedicated to the ancient god Nemesis, the ancient Greek god of revenge. In this case, why the people and the legionnaires have elected Nemesis as protector of the city and of the fortress? Maybe an answer will be known when the place and the ruins of the temple are found.

\section{A comparison between two historical defensive sites: Sucidava and Augusta Raurica}

Augusta Raurica is a Roman historical and archaeological site near the modern city Bâle, (20 km), Switzerland. It is the oldest known Roman colony on the Rhine. The connections in the Roman Empire were very good, using as way of communication the rivers or the roads. "Tabula Peutingeriana", shows this connections (itinerarium), using "cursus publicus” (the state-run courier and transportation service of the Roman Empire, later inherited by the Byzantine Empire; it was created by Emperor Augustus to transport messages, officials, and tax revenues from one province to another). In Figures 15 and 16 Sucidava can be observed (figure 15) and the possible road to Augusta Raurica, by Transylvania [12] (figure 16). In any case, the shortest way from Gallia to the Danube was the Rhine.

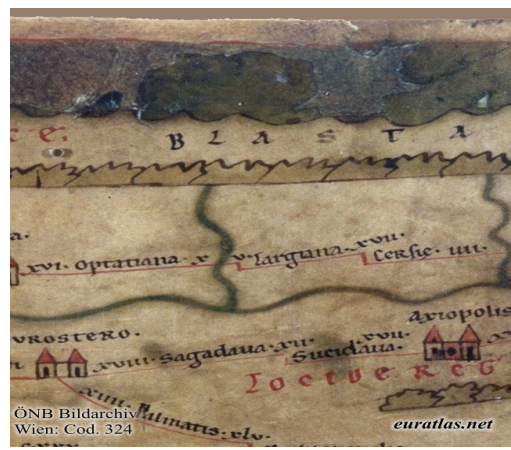

Figure 15: Roman roads near Sucidava (from Tabula Peutingeriana, ÖNB Bildarchive).

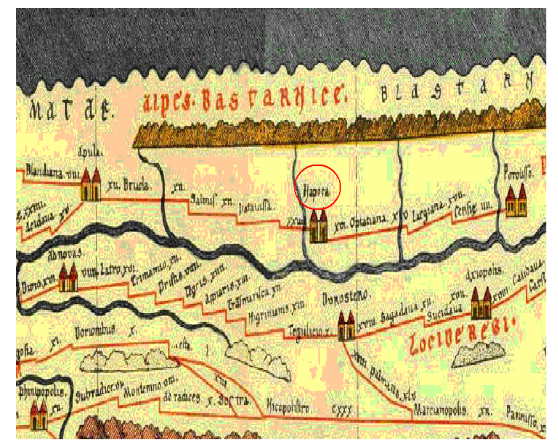

Figure 16: Roman road in central Transylvania (Tabula Peuntigeriana).

A comparison between the two sites - Sucidava and Augusta Raurica - is presented in Table 1. 
Table 1: $\quad$ Sucidava and Augusta Raurica; photos: *(L. Mitroi, Sept. 2011; **(D. Constantinescu, Sept. 2011.

\begin{tabular}{|c|c|}
\hline SUCIDAVA & AUGUSTA RAURICA \\
\hline $\begin{array}{l}\text { 1. Location: On the Danube River, at } \\
43^{\circ} 44^{\prime} 05^{\prime \prime} \mathrm{N} ; \quad 24^{\circ} 30^{\prime} 05^{\prime \prime} \mathrm{E}\end{array}$ & $\begin{array}{l}\text { 2. Location: On the Rhine River, at } \\
47^{\circ} 32^{\prime} 02^{\prime \prime} \mathrm{N} ; \quad 07^{\circ} 43^{\prime} 17^{\prime \prime} \mathrm{E}\end{array}$ \\
\hline $\begin{array}{l}\text { 3. Period of foundation } \\
\text { At the order of Emperor Aurelianus, } \\
270-275 \mathrm{AD}\end{array}$ & $\begin{array}{l}\text { 4. Period of foundation } \\
\text { By Lucius Munatius Plancus, at the order } \\
\text { of Iulius Cesar, } 44 \mathrm{BC} \text {; re-edification at } \\
\text { the order of Augustus, in } 15 \mathrm{BC}\end{array}$ \\
\hline $\begin{array}{l}\text { 5. Name and population } \\
\text { the name comes from the "Sykibid" } \\
\text { or " } \Sigma u c i " ; \text { from this: Sucidava } \\
\text { (see section 2) } \\
\text { about } 3000 \text { people in } 350 \mathrm{AD}\end{array}$ & $\begin{array}{l}\text { 6. Name and population } \\
\text { - the name comes from "Rauraci”, a local } \\
\text { Gallic tribe, relatives of Helvetii; no } \\
\text { archeological evidence found; Augusta } \\
\text { comes from emperor Augustus } \\
\text { - } 20.000 \text { people } \\
\text { (Schmidt [13]); (Belard-Laur [14]) }\end{array}$ \\
\hline $\begin{array}{l}\text { 7. Military } \\
\text { - location for the } \mathrm{V}^{\text {th }} \text { Legio Macedonica } \\
\text { and probably some connection with the } \\
\text { XIII Legio Gemina }\end{array}$ & $\begin{array}{l}\text { 8. Military } \\
\text { - Ala Moesica felix torquata (two } \\
\text { regiments of cavalry from Moesia } \\
\text { (see fig.5) } \\
\text { - Ala Hispanorum (cavalry of Hispania) } \\
\text { - Legio I Martia [13] }\end{array}$ \\
\hline $\begin{array}{l}\text { 9. Defence system } \\
\text { - defensive walls, (fig. 19) built during } \\
\text { Aurelianus, rebuilt during Constantine the } \\
\text { Great and Justinian } \\
\text { - bridge connection over Danube with } \\
\text { Ulpia Oescus }\end{array}$ & $\begin{array}{l}\text { 10. Defence system } \\
\text { - defensive walls, (fig. 20) built during } \\
\text { Augustus, rebuilt during Aurelianus, } \\
\text { Diocletian and Constantine the Great } \\
\text { - bridge system over the Rhine and its } \\
\text { local tributary }\end{array}$ \\
\hline $\begin{array}{ll}\text { Figure 19: } & \begin{array}{l}\text { Defence walls } \\
\text { Sucidava. }\end{array}\end{array}$ & $\begin{aligned} \text { Figure 20: } & \text { Defence wall at Augusta } \\
& \text { Raurica. }\end{aligned}$ \\
\hline
\end{tabular}


Table 1: $\quad$ Continued.

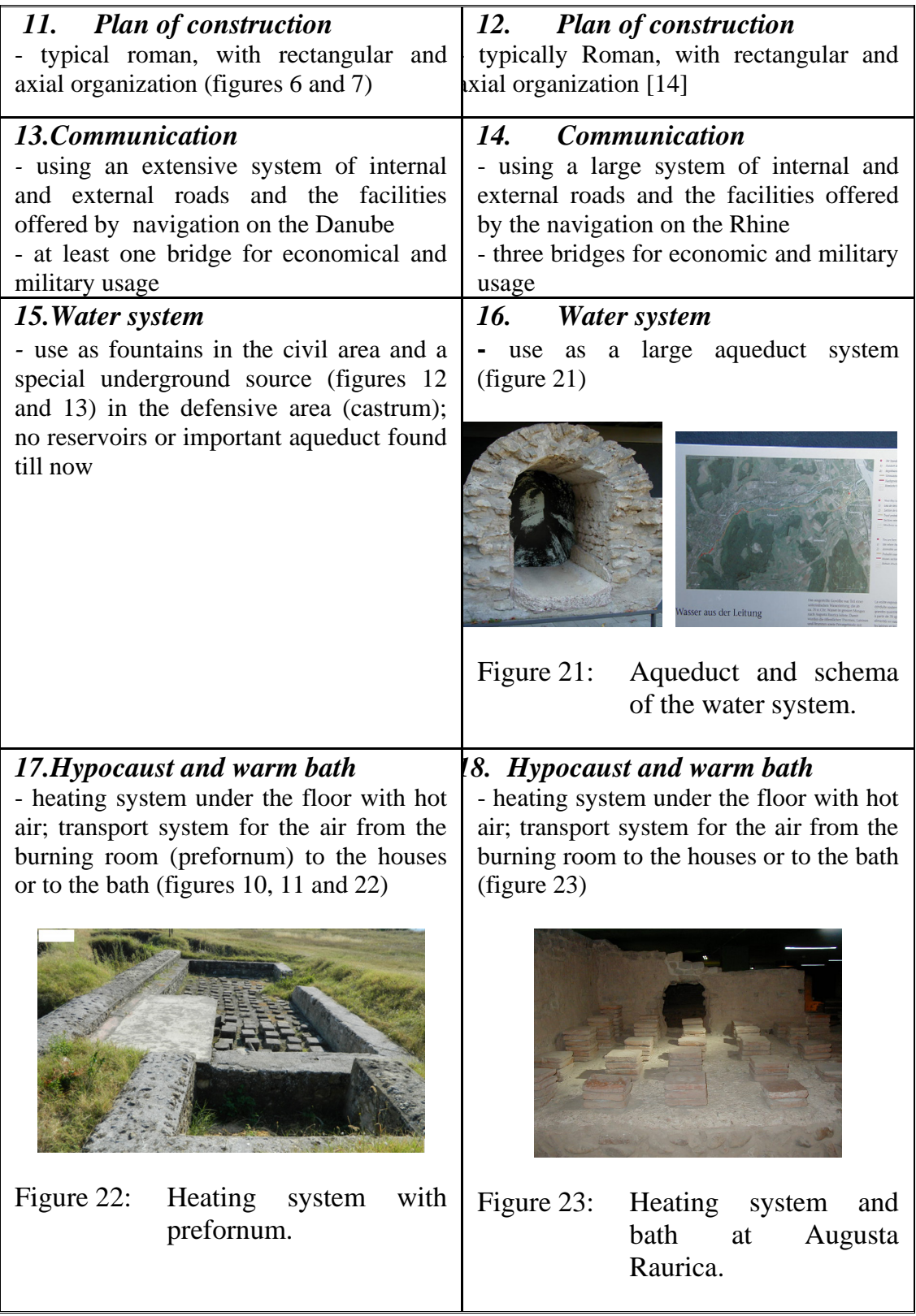


Table 1: $\quad$ Continued.

\section{Theatre and arenas}

- not discovered yet - a theater, amphitheater or arena, but the ruins must exist somewhere, highest probability in the area of the new modern buildings

\section{Theatre and arenas}

- one theater with up to 10.000 places (best preserved at the north of the Alps), (figure 24), one amphitheater and a gladiator arena

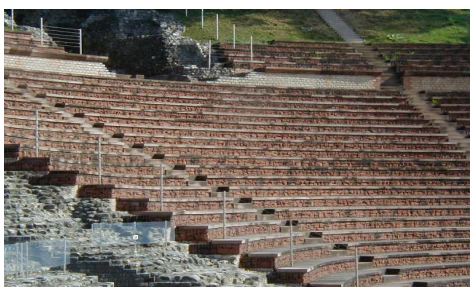

Figure 24: The 10,000 place theater at Augusta Raurica.

\section{Temples and mythology}

- the ruins of a temple are just in front of the theater (fig. 25) on the Schönbühl, but many authors do not mention which God it was dedicated to

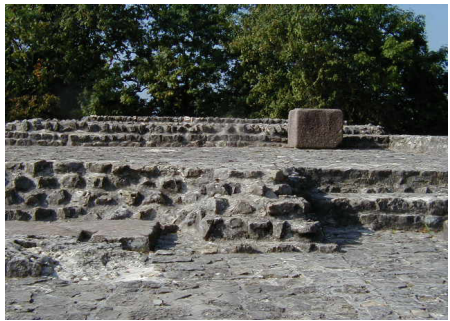

Figure 25: Ruins of the temple.

\section{Wars and step backs}

23. Wars and step backs

- 101-102 and 105-106 first and second Daco-Roman wars

- 270-275: hard attacks of all the Roman fortifications along the Danube, probably due to the German tribes

- 443-447 attack of the Sucidava city and fortress by the Huns

- about 580: the Roman Garrison abandoned the fortress and the city
- between 150 and 200 it was a flourishing period for the economy and the development of the city

- 275: hard attack and invasions by the German tribes of Allamans; after this, there are build new fortification

- about 300, new attacks; building of the fortification Castrum Saracens, one of the most important defensive bastion on the Roman border [13] 
Table 1: $\quad$ Continued.

\begin{tabular}{||l|l||}
\hline & $\begin{array}{l}\text { 24. Wars and step backs continued } \\
-351-352 \text { strong attack of the Germanic } \\
\text { tribes, stimulated by internal conflicts in } \\
\text { the Roman Empire } \\
-401 \text { diminution of the military presence } \\
\text { on the border of the Rhine } \\
- \text { about 600: the flourishing Augusta } \\
\text { Raurika is a small fishing village }\end{array}$ \\
\hline $\begin{array}{l}\text { 25. Paleo Christianity and } \\
\text { symbols } \\
\text { ruins of a Roman-Byzantine Basilica } \\
\text { from the 6th century; but the first symbols } \\
\text { of Christianity seem to be much earlier } \\
\text { (figure 26) }\end{array}$ & $\begin{array}{l}\mathbf{2 6} \text { Paleo Christianity and } \\
\text { symbols } \\
- \text { it is known that it was an ancient } \\
\text { Basilica, from about the 6th century, but } \\
\text { today only the place is well known }\end{array}$ \\
\hline $\begin{array}{l}\text { Figure 26: Symbol of the presence } \\
\text { of the first Christians in } \\
\text { Sucidava. }\end{array}$ &
\end{tabular}

\section{Discussion on the degradation process and environmental impact}

Over time, the ruins of Sucidava have undergone a process of progressive degradation, caused not only by nature but also by man (Constantinescu and Mitroi [15]).

Extensive damage was caused by invaders' fires, winds, rains, and freezethaw. The earth covered and the weeds invaded the sites.

Sucidava city knows some damage, it was first destroyed by the Huns (442447) and rebuilt in the years $527-533$ by Emperor Justinian, and was finally destroyed around the year 600 after the Slavic-Avar attacks.

Without doubt, over the centuries, many parts of stones and bricks used initially for the construction of the walls or for the buildings of ancient Sucidava were reused for other constructions. It is interesting to note the brick with the impregnation of the fish, the ancient symbol of Christianity (figure 28). The presence of the sign on a brick used for the construction probably means the presence between the workers or, may be between the legionnaires, of the first Christians in the area.

The first funds awarded to the Sucidava site were very modest and obtained with difficulty. Many archaeological finds from Sucidava have been 
photographed and recorded and then covered with soil for conservation. The rebuilding and restoration of the ruins were opened simultaneously, but, even today, the exact recipe of the concrete that lasted so many centuries has not been found.

Ancient Sucidava has a great potential to study the evolution of the defense system, with many vestiges to offer to those who study the history as well as for the tourist activities.

The natural environment makes every effort to cover what man has changed, once the human activity stops. Many problems regarding the environment are common for the two sites - Augusta Raurica and Sucidava. It is to remark that, starting with the 3rd century, the historical situation suffered many changes. In the years 1950-1965 some documents describe that many bands of barbarians (Alamans, other Germanic hordes ...) attacked the frontiers and destroyed the peaceful lives of the people. The affirmations are similar for Sucidava and for Augusta Raurica: the cities were often destroyed at high proportion due to the attacks and pillages. It was really easy to explain the troubles from the 3rd century in large territories due to the invasions from the years 259/260 and 270. But, in the last period, the archaeological, historical research in cooperation with the new theories regarding the problems of the environment and the theory of the systems looks critically to this dramatic scenario.

There are no more than forty years, during the cold war, the monocausales and radical explanations were frequent in the research activity. On the contrary, today the researchers of our globalized and complex world have explained the changes by the interference of a great number of elements, considering the world as a complex dynamic system. The Roman Empire was really such a complex and dynamic system. The crisis of this system took place over a long period of time and led to sustainable changes in most of its subsystems (provinces). Invasions were for sure a characteristic of the époque, but the economical, political and ecological problems also play an important role in this evolution. It is not possible to explain this evolution only by one or two years of catastrophes. The ecological impact on the environment had already begun during this period. The first constructions in Augusta Raurica as well as in Sucidava made use of wood, and the cities were organized in rectangular islands ("insulae"), as was typical for Roman architectural construction. Only after some decades were the constructions built in stone. This evolution was due to deforestation directly caused by the constructions, but also the constant need for wood in the process of fabrication of ceramic, the forges, the melting of bronze and for the heating of the "thermae". The wood becomes ever scarcer in the vicinity of Danube and the Rhine rivers. Besides, the constructions made of stones were more resistant to the fires and corresponded better to the demands of the local people, more and more Romanized. On the other hand, the fields had to produce more and more food for the increasing population and for more and more legionnaires garrisoned in the region to defend the borders of Empire.

Following these aspects, it is normal the pauperization and the diminution of the population starting with the second part of the 3rd century. It seems the limit was in the years 273...275 for Augusta Raurica and about 320 for Sucidava. These are only deductions, keeping in mind the archeological studies and some 
logical evolutions and impacts on the environment. In any case, we have to learn from the evolution of the Roman Empire, considered as a dynamic system, if we do not wish to make the same mistakes. Maybe, it is not too late.

\section{References}

[1] Bâciu, F., Vârtejaru, I. Monografia oraşului Corabia (The Monograph of the Corabia city), Edit. Alutus, Slatina, 2007, pag. 16-17, ISBN 978-9737947-24-6.

[2] Anastasiu, V. Harta fizică a României (Physical map of Romania); EDP, Bucharest, 2006.

[3] Karagiorgu, O. LR2 a Container for the Military annona, on the Danubian Border, chap. 7, page. 129-156, http://egg.mnir.ro/pdf/Karagiorgou Container.PDF

[4] Pârvan, V. Stiri nouă din Dacia Malvensis, Academia Română, Analele A.R. - Tom XXXVI, Mem. Sect. Istorice, nr.2, 1913 http://www.cimec.ro /Biblioteca-Digitala/Parvan/Parvan-

StiriNouaDdinDaciaMalvensis.htm? filename=ParvanStiriNouaDinDaciaMa lvensis.pdf

[5] Abraham Ortelius. Harta Daciei (translation from Latin language), Edit. Dacica, Bucharest, 2009, ISBN 978-606-92035-1-4.

[6] Hampartumian, N. Child-Burial and Superstitions in the Roman Cemetery of Sucidava (Dacia); Homage a Maarten J. Vermaseren, vol.68, part2, ed. E.J. Brill, Leiden, The Netherlands, 1978, ISBN 90-04-05668-8; 90-0405669-6, page. 473-478.

[7] Toropu, O., Tatulea, C. Sucidava - Celei, Edit. Sport-Turism, Bucharest 1987 page 219-225.

[8] Tudor, D. Sucidava, Edit. Scrisul Romanesc, Craiova 1974, pag. 130-140

[9] Tudor, D. Une cite daco-romaine et Byzantine en Dacie, Bruxelles Berchem, 1965, 140S, XXX S, Abb. $8^{\circ}$.

[10] Tudor, D. Decouvertes archeologoques a Sucidva et dans les environs, A.O., XVI, 1936.

[11] Gherghe, P., Amon, L, Petculescu, L. Cetatea Romano-Bizantina de la Sucidava, Preliminary Archaeological Report, National Archive, Record Site Code 125551.02, 2003.

[12] http://www.euratlas.net/cartogra/peutinger/7_thracia/thracia_4_1.html 1

[13] Schmid, D. Augusta Raurica, Augusta Raurica 2011/1, www.augustaraurica.ch

[14] Belard-Laur, R. Guide d'Augusta Raurica, Edit: Historische und Antiquarische Gesellschaft, Bâle, 5-eme edition 1991, ISBN 3-7151-50025.

[15] Constantinescu, D., Mitroi, L. Sucidava Archeological Site - a Remakable Cultural Heritage on the Danube River, The International BENA Conference Environmental Capacity Building, Nov. 2011, Bucharest, pag. 26, ISBN 978-606-8035-37-6. 